\title{
Relativization in English and Embosi
}

\author{
Dr. Ndongo-Ibara Yvon-Pierre ${ }^{1}$ \\ ${ }^{1}$ Université Marien Ngouabi, B.P. 69, Brazzaville-Congo
}

Correspondence: Dr. Ndongo-Ibara Yvon-Pierre, Université Marien Ngouabi, B.P. 69, Brazzaville-Congo. E-mail: ndongo_ibara7@hotmail.com/ndongo_ibara2002@yahoo.fr

Received: June 26, 2013

Accepted: July 19, 2013

Online Published: July 25, 2013

doi:10.5430/elr.v2n2p15

URL: http://dx.doi.org/10.5430/elr.v2n2p15

\begin{abstract}
The goal of this paper is to contrast the syntactic mechanisms that English and Embósí resort to derive relativization. It appears that relative pronouns are lexical property based in English whereas they are noun class prefix dependent in Embósí. In addition, they are postnominal in the two languages under discussion. Furthermore, relative pronouns are phonologically and morphologically free in English whilst they are bound morphemes and affixed to the verb in Embósí. In addition to subjacency conditions, locality principle, relativization resorts to copy theory to meet grammaticality requirements. What distinguishes the two languages is the lexical item that is copied. In this respect, when English makes use of preposition copying as a repair strategy to avoid ungrammaticality, Embósí, on the contrary, allows the copy of a pronoun that refers back to the noun that has been raised. Finally, this work confirms Accessibility Hierarchy Hypothesis as it illustrates subject, direct object, indirect object, oblique object and genitive relativization.
\end{abstract}

Keywords: Relativization, English, Embósí, Relative clause, Wh-movement, NP raising

\section{Introduction}

This paper examines the syntax of relativization. Put otherwise, I am concerned with the scrutiny of the grammatical properties and syntactic distribution of the relative pronouns. Some previous work shows that some studies on relativization concern the characteristics of the relative clause (Vries, 2002) whereas others deal with the identification of words that can be relativized in accordance with Accessibility Hierarchy Hypothesis (Keenan and Comrie 1977). Accordingly, relative pronouns are characterised by subordination, attribution and gap construction whereas the different words that can be relativized are language specific.

Examination of a set of works prove that there are fewer studies on relativization cross linguistics in keeping with its characteristics. As Murano and Pollock (2005:548) assert 'a comparative approach is of invaluable support' .In this respect, the main objective of this contribution is to compare the syntactic derivation of the relativization driving data from two languages from different language families namely English and Embósí. So, I want to find out the grammatical properties of the relative pronouns as well as highlight its syntactic distribution and constraints in English and Embósí. This paper addresses the following questions (1) What are the linguistic inherent properties of the relative pronouns in English and Embósí? (2) What is the syntactic position of the relative pronouns? (3) Does relative pronoun movement operation obey movement conditions? If no, what is the repair strategy that the two languages resort to? (4) what are the possible contentive words that can be relativized?

The article is organized as follows: Section 1 briefly recapitulates some of the arguments that have recently been adduced in favour of the syntactic description of relativization process in English. This lays the groundwork by showing in what way relativization is carried out starting from overt relative operator to invisible relative operator. Similarly, section 2 introduces relativization in connection with noun classes then moves on to deal with depicting words that can be relativized in Embósí. Section 3 concerns itself with the comparison of the relative pronoun properties, characteristics, syntactic position and relativizable words. Conclusion summarizes the key findings of this paper.

\subsection{Relativization in English}

This section discusses the syntax of the relativization process in English. By so doing, it analyses the different characteristics and properties that are taken into account when deriving this process. Firstly, according to Andrew 
Radford (2004:223) a relative clause contains "a relative pronoun (who/whose/which) that 'relates' (i.e. refers back) to an antecedent in a higher clause (generally one which immediately precedes the relative wh-expression)." This means that the relative clause is a clause whose derivation results from the incorporation of a relative pronoun into a construal to render it complex.

The derivation of relative clause obeys some syntactic properties that we are going to develop in the ensuing paragraphs. Syntactically speaking, the relative clause (henceforth $\mathrm{RC}$ ) can have the following obligatory properties:

Firstly, in English the RC is postnominal. That is to say, the RC is under the c-command of the NP that immediately dominates it. In this respect, the RC provides further information to its antecedent.

1 (a) The flowers that you sent me were lost.

(b) The President for whom you were waiting did not come.

(c) I am proud of the singer whose songs you like.

In the light of the examples in (1), one can observe that these sentences are made of two distinctive parts which delineate the boundary between the operator and its background part. What stands as the NPs on the top of the sentence represents an overt and phonetic form of a derived phrase. These NPs derive from their underlying base position which is the object of the predicate. This can be schematically given the following picture:

$2 \mathrm{NP} \_$Relative pronoun__ NP_

As things stand, the NP is subject to raising (Note 1) to a higher position of the same nature as its initial position. It must be stressed that the movement of the NP strictly obeys subjacency condition and Locality Principle to the extent that this NP movement is carried out within an authorized acceptable scope. Basing her attention on the raising NP, Edith Moravcsik (2006) puts forward language typology according to the accessibility hierarchy which reads as: «In all languages, if a constituent type is relativizable, all other constituent types to its left on the Accessibility Hierarchy are also relativizable». In this connection, Moravcsik, suggests the following language typology in terms of Accessibility Hierarchy as illustrated below:

3- a- Subject is relativized

The man who has given the book to the woman

b- Direct object is relativized

The book which the man has given to the woman

c- Indirect object is relativized

The woman to whom the man has given the book

d- Adverbial phrase is relativized

The book with which the man replaced the notebook

e- Genitive is relativized

The book whose cover was designed by the man

$\mathrm{f}$ - Standard of comparison is relativized

The book which the newspaper article is better than

(Moravcsik, 2006:222)

The examples in (3) illustrate six (06) types of constituents which are capable of being relativizable. Furthermore, English is one the few languages all over the world that instantiate all these six RC types. The six types of RC are summarized as follows

(4) Type1 Languages where only subjects are relativizable

Type2 Languages where only subjects and direct objects are relativizable

Type3 Languages where only subjects, direct objects and indirect objects are relativizable

Type4 Languages where only subjects, direct objects, indirect objects and oblique

objects are relativizable 
Type 5 Languages where only subjects, direct objects, indirect objects, oblique objects and genitives are relativizable

Type 6 Languages where only subjects, direct objects, indirect objects, oblique objects, genitives and standard comparison are relativizable

(Moravcsik, 2006:224)

In addition to their postnominal position, English $\mathrm{RC}$ are accessible via an overt or covert marker/operator. Put otherwise, the RC is visible lexically by the presence of a relative operator which confirms the syntactic property of RC.

(5) a- The baby who/that is foxy

b- The house which is opposite our temple

c- The black girl whom I saw

d- The village where I was born

e- The time when I defended my Ph.D.

f- The reason why I married you

g- The way in which you rule your company

h- What I do best is teaching grammar

In the above examples, there are several overt forms of the relative markers. Traditionally, people only think of the pair who/that and which/that which represent the core relative pronouns. But in addition to these traditional pronouns, it is worth mentioning that once these pronouns occur after nouns denoting places, times, reasons, and manners ; they are subject to lexical change. This means that who/which are going to be replaced by where, when, and why in order to obey the lexical content and properties of its antecedent. Except the example 5 (h), all the other spell-out of the relative pronoun can be given a bare relative form, i.e., these relative pronouns can be omitted at PF without generating any deviancy. This is supported by Jeanette S. DeCarrico (2000:162)who asserts that 'if the relative pronoun functions as an object, another option in "zero" relative pronoun (no pronoun at all). The option is available regardless of whether the pronoun is whom or that.'

Furthermore, the RC instances subject verb agreement in the clause. That is to say, even though the form of the relative pronoun does not change according to the number of its antecedent, but the verb that follows the relative pronoun must agree with the NP that immediately dominates it. This is illustrated in the examples hereafter:

(6) a- The university which is located in Brazzaville

b- The universities which are located in Tchikapika

Finally, the RC in English triggers the predicate within the clause to be finite. This is supported by all the examples above. What is interesting to argue now is the fact that the relationship between the operator or pivot with its antecedent is based on coreferentiality. This is to mean that the operator carries the same grammatical information of the NP above. In the literature on generative, this link was best termed as co-indexation as expounded by Liliane Haegeman (1991:371)

'We assume that the interpretation of the relative pronoun is achieved through a rule of co-indexation where the [the man] and [whom] end up having the same index. This co-indexation is used to represent the fact that the relative pronoun modifies or is 'predicated of' [the man], it is a predicative rule'

What can be understood from Haegeman's statement is that the relative clause said something on its antecedent. As a first conclusion, the relative clause in English is embedded in the Noun phrase and can be given the following rewrite rule :

(7) NP----------N-bar + S(Comp).

Basing upon this syntactic rules, the example (5a) can have the following representation: 
$(8)$

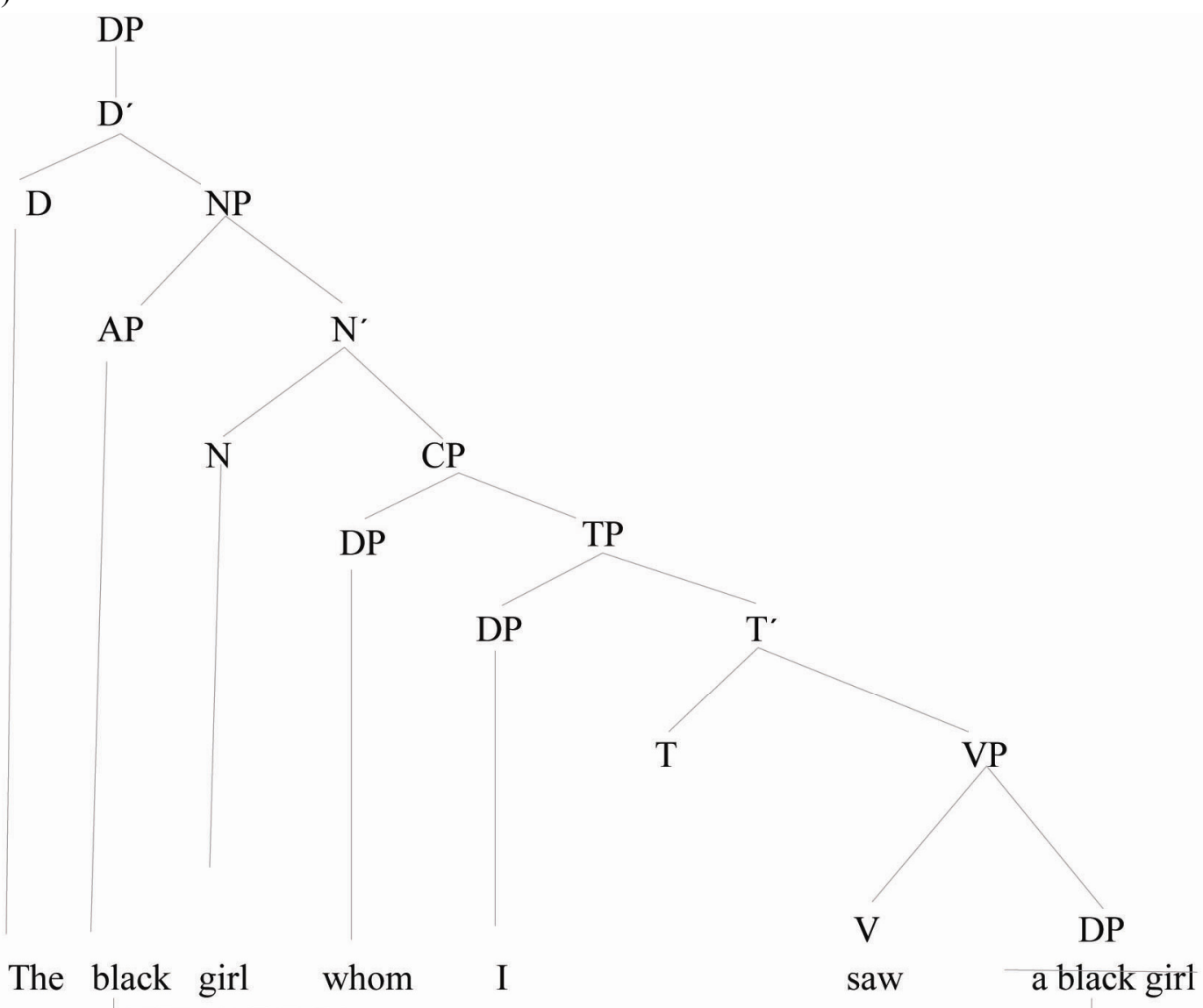

In the ensuing lines we are going to analyse how in Embósí the relative clause is processed syntactically.

\subsection{Relativization in Embósí}

As Embósí is not of the same language family as English, it is natural to claim that it will have a different grammatical system that accounts for RC. This is the concern of this section.

Firstly, the relative pronoun is a bound morpheme that is affixed to the prefix position of the predicate. In addition, this relative pronoun closely depends on the noun class of the NP that c-commands it as in:

(9)

\begin{tabular}{|c|c|c|c|c|}
\hline $\begin{array}{l}\text { Class } \\
\text { number }\end{array}$ & Number & Noun class & $\begin{array}{l}\text { Resumptive } \\
\text { relative pronoun }\end{array}$ & examples \\
\hline \multirow[t]{6}{*}{1} & \multirow[t]{4}{*}{ Singular } & mù & yé & $\begin{array}{l}\text { mwánà yé-dzwé mbóà 'The child who went home' } \\
\text { child Rel-go village }\end{array}$ \\
\hline & & mò & yé & $\begin{array}{l}\text { mòró yé-yémbà òdzémbé 'The man who sings a song' } \\
\text { person Rel-sing song }\end{array}$ \\
\hline & & ò & yé & $\begin{array}{l}\text { òlómì yé-bá } \\
\text { husband Rel-marry you }\end{array}$ \\
\hline & & no marker & yé & 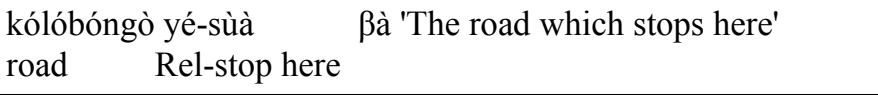 \\
\hline & \multirow[t]{2}{*}{ Plural } & bá & bá & $\begin{array}{l}\text { bánà bá-dzwé mbóà' The children who went home' } \\
\text { children Rel-go village }\end{array}$ \\
\hline & & bá & bá & $\begin{array}{l}\text { àlómì bá-wùrù kó 'The husbands who came from the forest' } \\
\text { husbands Rel-come from forest }\end{array}$ \\
\hline
\end{tabular}




\begin{tabular}{|c|c|c|c|c|}
\hline 2 & \multirow[t]{2}{*}{ Singular } & mù & mo & $\begin{array}{l}\text { mùndà mò-sómbí wà 'the lamp that he bought' } \\
\text { lamp Rel-buy him/her }\end{array}$ \\
\hline 2 & & ò- & mo & $\begin{array}{l}\text { òlàngì mòbwéé wà 'the bottle that s/he threw away' } \\
\text { bottle Rel-throw him/her }\end{array}$ \\
\hline 2 & \multirow[t]{2}{*}{ Plural } & mí & mí & $\begin{array}{l}\text { míndà mí-sómbí wà 'the lamps that he bought' } \\
\text { lamps Rel-buy him/her }\end{array}$ \\
\hline 2 & & mì & mì & $\begin{array}{l}\text { ìlàngì mì-bwéé wà 'the bottles that s/he threw away' } \\
\text { bottles }\end{array}$ \\
\hline 3 & \multirow[t]{2}{*}{ Singular } & dí & li & dísí lí-té bwà 'The eye that has been hurt' \\
\hline 3 & & ì & & $\begin{array}{l}\text { ìkò li-dì } \text { nò odzàà 'The banana that you ate' } \\
\text { banana Rel-AUX you eat } \\
\text { ißó lì-kyé nò ìdì ìbé What you did is bad } \\
\text { problems Rel-do you it-be bad }\end{array}$ \\
\hline 3 & \multirow[t]{3}{*}{ Plural } & mí & mà & $\begin{array}{lll}\begin{array}{l}\text { mísí } \\
\text { eye }\end{array} & \text { mà-té } & \text { bwà 'The eye that has been hurt' }\end{array}$ \\
\hline 3 & & à & mà & \begin{tabular}{|lcc} 
àkò & mà-díi & nò odzàà 'The banana that you ate' \\
banana & Rel-AUX you eat &
\end{tabular} \\
\hline 3 & & $\begin{array}{l}(\varnothing) \\
\text { morpheme }\end{array}$ & yé & $\begin{array}{l}\text { pó yé-kyé nò ìdì ibé What you did is bad } \\
\text { problems Rel-do you it-be bad }\end{array}$ \\
\hline \multirow[t]{4}{*}{4} & Singular & è & yé & $\begin{array}{l}\text { èkò yé-kòsì 'the foot that has been wounded' } \\
\text { foot Rel-wound } \\
\text { èyéà yé-lémbí 'the object that has been lost' } \\
\text { thing Rel-lose } \\
\text { èléngé yé-dí là àporà 'The face which has wounds' } \\
\text { face Rel-be with wounds }\end{array}$ \\
\hline & \multirow[t]{3}{*}{ Plural } & à & mà & $\begin{array}{l}\text { àkò mà-kòsíngí ' the feet that have been wounded' } \\
\text { feet } \\
\text { Rel-wound }\end{array}$ \\
\hline & & b- & bi & $\begin{array}{l}\text { béà bí-lémbi 'the objects that have been lost' } \\
\text { things Rel-lose }\end{array}$ \\
\hline & & í & $\mathrm{mi}$ & $\begin{array}{l}\text { liléngé mí-dí là àporà 'The faces which have wounds' } \\
\text { faces } \quad \text { Rel-be with wounds }\end{array}$ \\
\hline \multirow[t]{2}{*}{5} & Singular & nasal & yé & $\begin{array}{l}\text { ndáí yé-tóngí tómí 'The house that is built by my brother' } \\
\text { house Rel-build elder brother }\end{array}$ \\
\hline & Plural & à & mà & $\begin{array}{l}\text { àndáí mà-tóngí tómí 'The house that are built by my brother' } \\
\text { house Rel-build elder brother }\end{array}$ \\
\hline \multirow[t]{2}{*}{6} & Singular & lè & li & $\begin{array}{l}\text { lèkásí } \quad \text { li-kyémbímí 'The letter that has been written' } \\
\text { letter } \quad \text { Rel-Write-Passiv }\end{array}$ \\
\hline & Plural & $\begin{array}{l}(\varnothing) \\
\text { morpheme }\end{array}$ & yé & $\begin{array}{l}\text { kásí yé-kyźmbímí 'The letters that have been written' } \\
\text { letters Rel-Write-Passiv }\end{array}$ \\
\hline \multirow[t]{2}{*}{7} & Singular & bù & bo & $\begin{array}{l}\text { bwárí bo-kyé ngá 'The canoe that I made' } \\
\text { canoe Rel-make me }\end{array}$ \\
\hline & Plural & má & mà & $\begin{array}{l}\text { márì mà-kyé ngá 'The canoes that I made' } \\
\text { canoes Rel-make me }\end{array}$ \\
\hline
\end{tabular}


There are a number of observations worthy of attention. Firstly, even though the resumptive relative pronouns are not always the copy of the noun class, they do depend on them. Denis Creissels (1991:459) examining the relative pronoun in Tswana comes to conclusion that

'... l'antecedant est relié à la relative par un connectif qui varie selon la classe de l'antécédant mais ne porte aucune trace de la fonction du pivot de la relativization de la structure relativisée(Note 2)'

If in Tswana the relative pronoun and the antecedent are linked by a connector, in Embósí on the contrary, there is no connector. Of interest is the fact that either the connector in Tswana or the relative pronouns in Embósí depend on the noun class of their antecedents. In addition, they do not carry particular reference of the grammatical functions of their antecedents. What all this means is that the form of the relative pronoun does not tell something about the function of the NP that c-commands it.

Secondly, the morphological form of the relative pronoun as one can realise from the examples on the chart, in Embósí agrees in number with its antecedent. The singular and plural forms of the relative pronouns are asymmetrical.

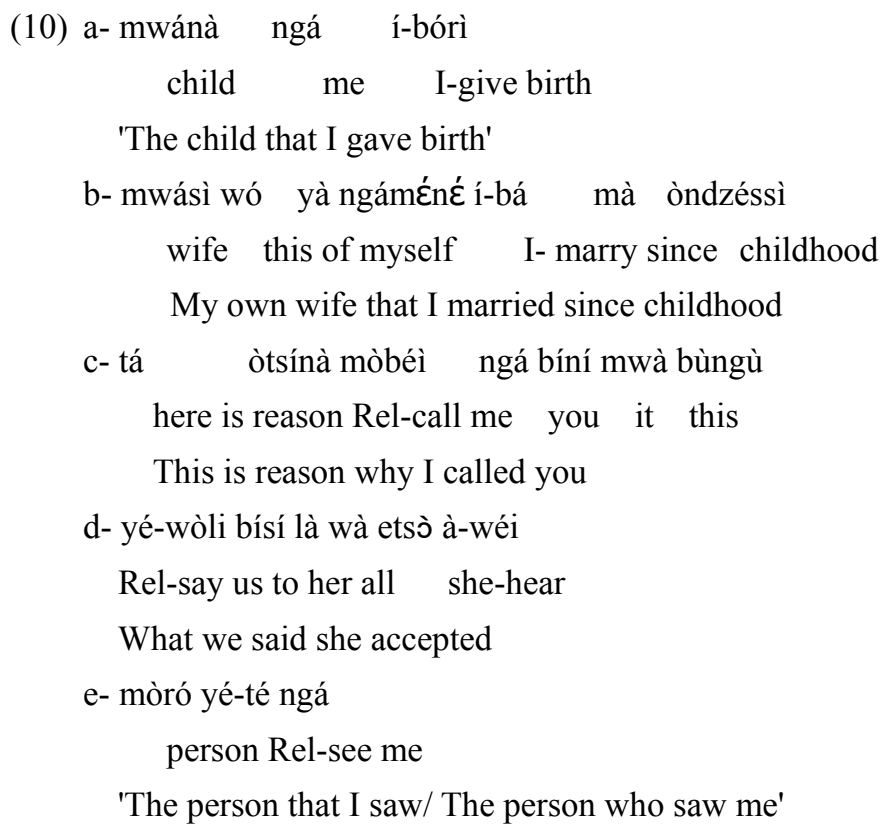

The examples in (10) illustrate a number of other characteristics of relative clause formation in Embósí. Let's start with (10e) and argue that the RC in Embósí can raise some semantic ambiguities. This semantic ambiguity is related to the fact that the relative pronoun interpretation does not provide a straight forward sense. Put otherwise, instead of being 'predicated of', the relative clause is 'empty'. The empty property of the relative clause is due to the fact that neither the antecedant nor the pivot of the relativization c-commands the other. We are facing a case where the relative clause interpretation is bidirectional. This bi-directionality is accounted of in terms of the NPs that are involved in the clause which are animate, that is, capable of undertaking an action. If we want to draw the distinction between the two interpretations, we have to resort to the auxiliary 'idzema' as illustrated below:

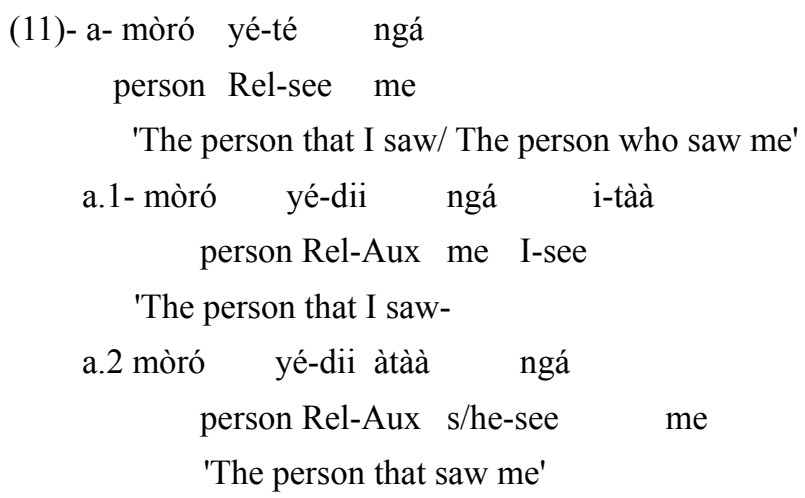


The examples (11a.1 and 11a.2) illustrate a case of object and subject relativization. In the example (11a.1) the NP 'moro' has been raised upward from its base object post verbal position, but in (a.2) the NP 'moro' does not make any movement despite the fact that under VP Internal Subject Hypothesis which postulates that the subject NP moves from its specifier position under VP to its spec-T position where it is assigned a nominative case. To quote Radford (2009:241)

The claim that (non-expletive) subjects like some students/lots of students in sentences like (1) originate internally within the VP containing the relevant verb (and from there move into spec- $T$ in sentences like (1) above) is known in the relevant literature as the VP-Internal Subject Hypothesis (=VPISH)

In the example (10a), we have another case of relativization where the the raising of the NP does not imply the relativization. It looks like an NP raising as in topicalisation or fronting. This corroborates what Denis Creissels (1991:460) asserts that there are languages which illustrate something different

'Mais on peut aussi trouver des cas où la relative apparaît immédiatement juxtaposée à son antécédant. L'anglais atteste un cas extrême où on peut n'avoir aucune marque morphologique de la relativisation (Note 3).

It is worth mentioning that we cannot postulate for a bare relative pronoun because in Embósí the relative pronoun (Note 4) which modifies a noun is always a bound morpheme which is attached to the predicate. The example demonstrates that languages with long oral tradition have a very complex syntax as orality is compared to a 'free puzzle'. In discourse, this kind of construction is mainly found when the speaker is complaining, worrying or regretting about the behaviour of someone. We can find the same construction in other Bantu languages such as Lingala, Tegue as exemplified in:

$\begin{array}{cl}\text { (12) a- Mwánà } & \text { na-bóti } \\ \text { child } & \text { I-give birth }\end{array}$

'The child that I gave birth' (Lingala)

b-Tàlà bùli ndé

father give birth you

'The father who gave you birth' (Tege)

In the examples (12), we have relativization process which is carried out without an overt morphological marker of the relative pronoun. The above illustration can be associated with zero relative hypothesis as, for example, the $N P$ 'mwanà' is an object. In the words of Charles Meyer (2009:134) 'When objects are relativized, it is also possible to omit the relative pronoun altogether, creating a clause containing what is sometimes referred to as a zero relative'.

In the ensuing we aim to find out whether the Embósí language can attest all the six types of relativization. In this respect, we can consider the following examples.

$\begin{aligned} \text { (13) a- ibàà } & \text { li-dii i-péć bùkù là oyírí } \\ \text { man } & \text { Rel-AUX he-give book to wife }\end{aligned}$

'The man who gave the book to the man'

$$
\begin{aligned}
& \text { b- bùkù bo-dii ibàà a-péć là oyírí } \\
& \text { book Rel-AUX man he-give to woman }
\end{aligned}
$$

'The book which the man gave to the woman'

c- bùkù bo-dii ibàà à-kyźmbèċ là bwá
book Rel-AUX man he-write with it

The book with which the man has written

$$
\begin{array}{rlrl}
\text { d- bùkù bo-dii àngá } & \text { bwá à-pùràà } \\
\text { book } & \text { Rel-AUX owner it } & \text { he-look for }
\end{array}
$$

'The book whose owner was lookiing for' 


$\begin{array}{lllll}\text { e- oyírí } & \text { yé-dii } & \text { ibàà } & \text { a-péć } & \text { bùkù là wà } \\ \text { woman } & \text { Rel-AUX } & \text { man } & \text { he-give } & \text { book to him }\end{array}$

'The woman to whom the man gave the book'

The examples (13a and 13b) illustrate typical relativization where the subject and the object are relativized. But the other examples are quite atypical in connection with all the processes that are involved during this relativization. Regarding the example (12c), we are quite dealing with left dislocation. In fact, there are two syntactic processes that take place during that process notably the NP raising implying the relativization and the pronominalization. It is worth mentioning that if the later process is not taken into account the sentence will be ungrammatical. This means that the relativization of the indirect object and adverbial phrase is generally carried out together with the pronominalization of the raised NPs.

When the indirect object is raised to the subject position of the NP in the sentence, this movement violates the CED and FHC conditions (Note 5). As a result, the NP is preposed alone leaving behind the preposition that dominates it. As stated earlier, one can assume that it looks like a case of left dislocation because the island from where the NP has been extracted is not empty. I have to claim that the example (12e) has nothing in common with left dislocation. To quote Haegeman (1991:379) discussing left dislocation writes '...a movement analysis is inappropriate [...] left dislocation is not the result of movement'. However, we assume that in (12e), there is movement of the NP 'oyiri'. An argument of support can be drawn from Radford (2004:192-193) when he talks about preposition copying basing on copy theory. Let us consider Radford's examples as a starting point:

(14) a- IKEA only actually has ten stores [from which to sell from] (Economics reporter, BBC

Radio 5)

b- Tiger Woods (about whom this Masters seems to be all about) is due to tee off shortly (Sports reporter, BBC Radio5)

c- Israeli soldiers fired an anti-tank missile and hit a police post (in which the Palestinian policeman who was killed had been in (News reporter, BBC Radio 5)

d- In what enormity is Marcius poor in? (Menenius, Coriolanus, II.i)

e- ... that fair (for which love groan'd for (Prologue to Act II, Romeo and Juliet)

(Radford, 2004:192)

In the examples (14), we can observe that when the preposition is moved from its extraction site to its landing site, it leaves a copy behind. Accordingly Radford (2004:193) explains this process in the following lines:

Let's suppose that wh-movement (like head movement) is a composite operation involving two suboperations of copying and deletion: the first stage is for a copy of the moved wh-expression to be moved to spec-CP; the second stage is for the original occurrence of the wh-expression to be deleted. From this perspective, preposition copying arises when the preposition at the original extraction site undergoes copying but not deletion.

Similarly, if English here exemplifies a case of preposition copying, we postulate for the anaphoric noun copying to account for the Embósí examples in (13). Accordingly, this Embósí anaphoric noun copying is a way of avoiding ungrammaticality. In addition, when the complement of the preposition is moved, if the extraction position where the $\mathrm{NP}$ vacated is empty, the construal will be odd and ungrammatical.

Everything considered, I can assume that Embósí attests five types of relativization namely subject, direct and indirect object, genitive and adverbial. What must be emphasized here is that the relativization does not always require the same phases in its derivation. Syntactically, the RC in Embósí looks like the following structure.

(14) NP----------N-bar + S (Comp).

The example (13b) can be attributed the tree diagram in (15) as follows: 


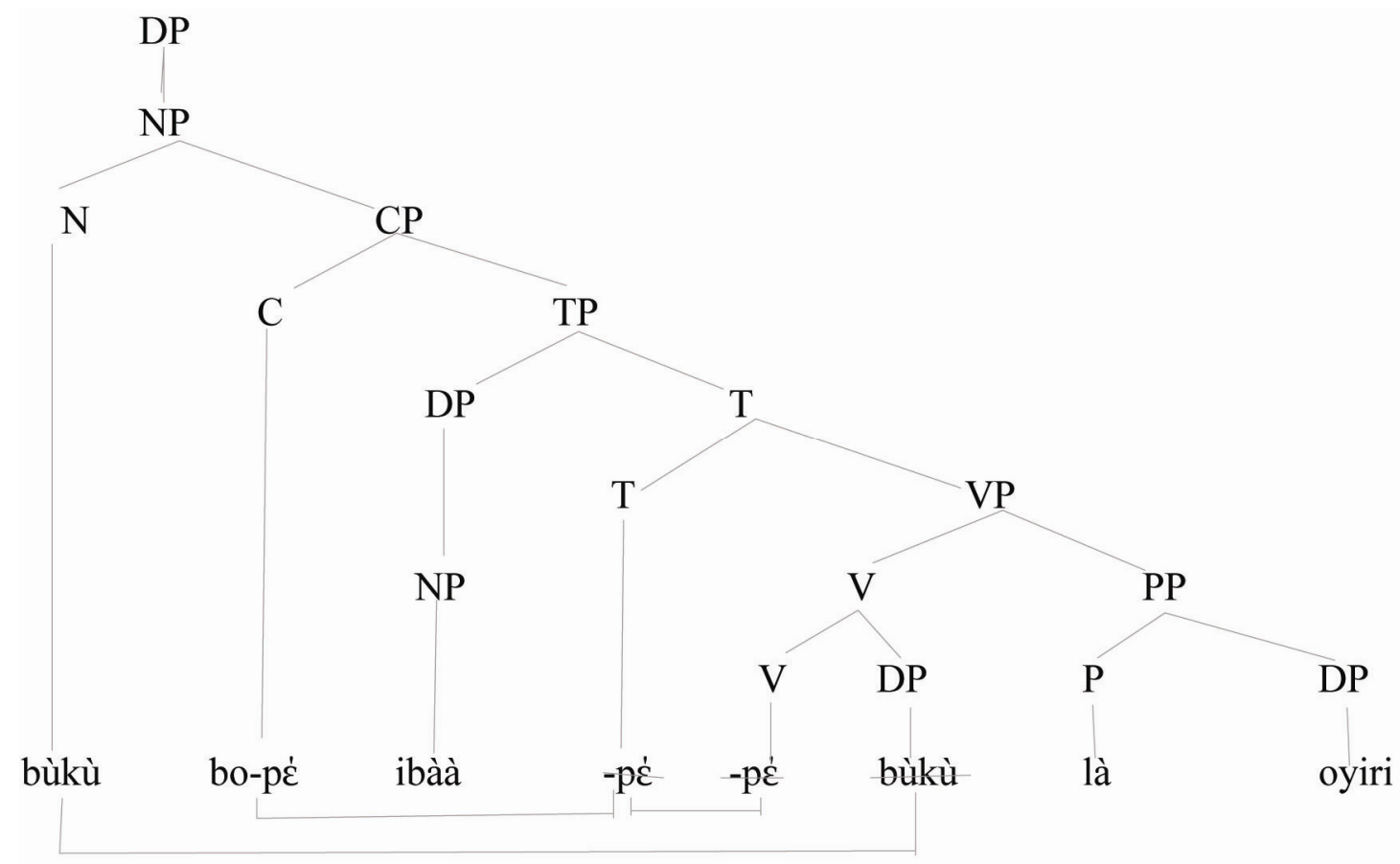

In the following lines, we are going to highlight the similarities and dissimilarities concerning relativization in the two languages under discussion.

\section{Contrastive analysis}

In this section, we are going to highlight the common characteristics of the relativization in the two languages under discussion.

\subsection{Similarity}

English and Embósí make use of the relative pronoun for the derivation of the relativization process. In addition, in the two languages, relativization implies the movement of a constituent. Furthermore, the relative clause requires the predicate to be finite as well as show agreement between the subject, antecedent and its predicate. Finally, the two languages agree on the fact that relative clause are post nominal constituents. Mark de Vries (2002:73) summarizes the relativization as follows:

a- the structure $\left[D P\left[D^{\prime} D\left[N P\left[N^{\prime} N_{i}\left[C P\right.\right.\right.\right.\right.$ w $\left.\left.\left.\left.\left.h_{i} \ldots t_{i} \ldots\right]\right]\right]\right]\right]$

b-assumptions:

- $\quad$ P rel is the complement of $N$

- there is wh-movement o SpecCP (by an empty operator or a relative pronoun)

- there is co-indexing between wh and the head $N$

\subsection{Dissimilarities}

Regarding the differences we find out in this scrutiny; we argue that the form of the relative pronoun is the first element that differentiates the two languages. As a matter of fact, when the form of the relative, except that, depends on the lexical properties of the noun that c-commands the relative in English, in Embósí, on the contrary, the morphological form of the relative closely depends on the grammatical properties of the noun class of the noun that dominates the relative.

In addition, when the relative pronouns are independent lexical morphemes in English, those of Embósí are dependent and bound morphemes. As a result, there is no distinction between [+human] and [-Human] properties of the noun in connection to relativization process in Embósí; what distinction is a must in English.

Another support of argument that shows dissimilarities between the two languages is related to the use and omission of the relative pronoun. In English, when the relativizable constituent is an object, the relative pronoun can be 
invisible. Embósí instantiates quite a similar feature, but as relatives are bound morphemes, we cannot postulate such an hypothesis.

Moreover, when English attests all the six (06) types of relativization process, Embósí only attests five of them. As exemplified in examples (14), English allows preposition copying during the formation of relative clause, but Embósí on the contrary permits anaphoric noun copying under the same procedure.

\section{Results}

The key results of this contrastive analysis on relativization can be summarized as follows:

(1) Inherent properties of the relative pronouns

\begin{tabular}{|l|l|}
\hline Embósí & English \\
\hline Noun class prefix of the antecedent & Antecedent feature: \\
& + Human = Who \\
& - Human = Which \\
& \pm Human= that \\
\hline
\end{tabular}

(2) Syntactic distribution of the relative pronoun

Embósí

English

The relative pronoun is postnominal in the two languages under discussion

(3) Relativization and wh-movement conditions

\begin{tabular}{|l|l|}
\hline Embósí & English
\end{tabular}

Wh-movement conditions are respected if we consider copy theory to account for preposition copying

Wh-movement conditions are respected if we consider copy theory to account for anaphoric noun copying

(4)Relativizable items

\section{Embósí}

Subject, direct object, indirect object, object object, genitive.
English

Subject, direct object, indirect object, object object, genitive, standard comparison

\section{Conclusion}

In this paper, we have discussed relativization under cross-linguistic perspective. As Li Chiu-Ming and Li Li write (n.a:74) 'However different relative clauses may appear from language to language, they are on the whole similar to one another in underlying structures'. From this discussion, it follows that Chomsky's postulation of the Universal grammar properties is still explanatorily adequate as language analysis confirms this hypothesis.

In the two languages under discussion, the relative clause has grammatical properties that govern it. These properties are inherent to the noun that immediately dominates the relative marker notably the number (Embósí) or the features \pm human (English).

Finally, the relativization process is constrained by subjacency conditions in that the movement takes place within the same structure. Even though the two languages violate Conditions on Extraction Domain and Functional Head Constraints regarding preposition copying in English and anaphoric noun copying (Embósí) in connection to the formation of the relative clause, the copying operation is taken differently by each language. When English allows the copy of the preposition, Embósí permits the noun copying. We agree with Mark de Vries (2002:69) that 'There is a common syntactic basis to all types of relatives, and [...] the parameters and additional mechanisms are that cause the differences'. Finally, this investigation confirms that Accessibility Hierarchy Hypothesis still holds as this paper illustrates subject, direct object, indirect object, oblique object and genitive relativization. 


\section{References}

Chomsky, N. (1977). On Wh-Movement. In Formal Syntax. P. Culicover et al., eds. Academic Press, New York, 71-132.

Creissels, D. (1991). Description des langues Négro-africains et théories syntaxiques. Grenoble: ELLUG.

DeCarrico, Jeanette S. (2000). The Structure of English: Studies in Form and Function for language Teaching. USA: University of Michigan Press. 2000.

Haegeman, L. (1994). Introduction to Government and Binding Theory. Second edition. Blackwell, Oxford.

Jackendoff, R. (1977). X-Bar Syntax: A Study of Phrase Structure. Cambridge, Mass.: MIT Press.

Keenan, E. \& B. Comrie. (1977). Noun Phrase Accessibility and Universal Grammar.Linguistic Inquiry 1977; 8: 63-99.

Li Chiu-Ming \& Li Li. (2013). Relativization in English and Chinese http://www.ifa.amu.edu.pl/psicl/files/29/05ChiuMing\&LiLi.pdf. (13 June 2013, dtae last accessed)

Meyer, C. F. (2009). Introducing English Linguistics. Cambridge: CUP.

Moravcsik, E, A. (2006). An Introduction to Syntax. London \& New York: Continuum.

Murano, Nicola \& Jean Yves Pollock. (2005). Qu'est-ce que, (que) est-ce que: A case study in Comparative Romance interrogative syntax. In The Oxford Handbook of Comparative Syntax Cinque, ed. 2005,542-606.

Ndongo-Ibara,Y.-P. (2009). A Comparative Study of Embosi and English Complements. PhD Thesis, Université Marien Ngouabi, Brazzaville, 2009.

Radford, A. (2004). Minimalism Syntax: Exploring the Structure of English. Cambridge: CUP. 2004. http://dx.doi.org/10.1017/CBO9780511811319

Radford, A. (2009). Analysing English Sentences: A Minimalist approach. Cambridge, CUP. 2009. http://dx.doi.org/10.1017/CBO9780511801617

Ross, J. (1967). Constraints on Variables in Syntax. PhD thesis, MIT. Reprinted as Infinite Syntax! (1986). ABLEX Publishing Corporation, Norwood, New Jersey.1967.

Smith, C. (1964). Determiners and Relative Clauses in a Generative Grammar of English. Language 1964; 40 : $37-52$. http://dx.doi.org/10.2307/411923

Smits, R. (1988). The Relative and Cleft Constructions of the Germanic and Romance Languages. Doctoral dissertation, Katholieke Universiteit Brabant. Foris, Dordrecht.

Vries, M. de. (2002). The Syntax of Relativization. PhD thesis,Universiteit van Amsterdam.2002. 


\section{Notes}

Note 1. There is an abundant literature on the nature of the Relative clause. According to Smith (1964), RC is the complement of D, whilst it is an adjunct of the NP according to Ross (1967). Jackendoff (1977) deals with restrictive and appositives. For him restrictive which refers to RC are c-commanded by D. Smits (1988) using the X-bar hypothesis assserts that restrictives are adjoined to N-bar whereas appositives are adjoined to DP. Chomsky (1977) considers RC as element of wh-expressions which are syntactically explained using wh-movement. To have further information readers are advised to read the above literature together with Mark de Vries (2002) 'Syntax of relativization'

Note 2. The antecedant is related to the relative clause by a connector which varies according the noun class of its antecedent, but it does not bear any index/reference on the grammatical function of the relativization pivot within the relativized structure (my translation)

Note 3. There are some cases showing a relative immediately following its antecedent. In English, we can find a construction with no overt morphological marker of the relative pronoun. (my translation).

Note 4. In Embósí only the relative pronoun which modifies a verb is a free morpheme (Readers can find further information on the issue in the chapter five of Ndongo Ibara 2009. Let us consider the following examples:

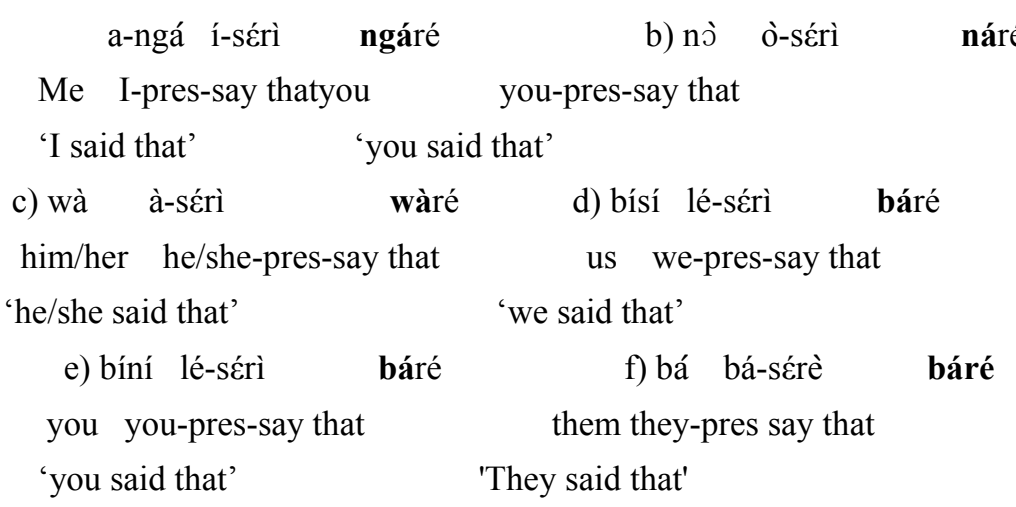

(Ndongo Ibara, 2009: 378)

As we can observe from the above illustration, the relative pronoun 'That' is not affixed to the prefix of the verb. In addition, contrary to the $\mathrm{RC}$ which is post nominal, the relative pronoun in the complex sentence is post verbal and free morpheme.

Note 5. Conditions on Extraction Domain (CED) and Functional Head Constraint (FHC) specify the domain where an item has to be moved together with the conditions determining this movement. The FHC strongly recommends that when processing a movement, it must only and only concern the whole phrase, but not a part of it. However, the fact that in Embósí the movement of the NP which was an oblique object is carried out leaving the preposition at its base position is the contrary of the two movement conditions. This illustrates a case of preposition stranding which is not to be considered as syntactic deviancy, but syntactic idiosyncrasy. 